\title{
Hisse senedi endeksi ile tüketici güven endeksi arasındaki ilişkinin Granger nedensellik testi ile incelenmesi
}

\author{
Cansu ÇiLingiR ${ }^{a}$
}

${ }^{a}$ *istanbul Aydın Üniversitesi, I.i..B.F, Muhasebe ve Finans Yönetimi Bölümü, e-posta: ccilingir@aydin.edu.tr, Orcid: 0000-0001-5923-9700

MAKALE BILGILERi

Araştırma Makalesi Geliş Tarihi 5 Aralık 2020

Revizyon 14 Mart 2021

Revizyon 15 Mart 2021

Kabul tarihi 19 Mart 2021

\begin{abstract}
Güven endeksleri, hane halkının mevcut ve gelecekteki davranışlarına yönelik tutumlarını incelediğinden, ekonomiye yönelik genel bir kanı oluşturmaktadır. Bu kararların hisse senedi endeksleri ile ilişkili olduğu düşünülmektedir. Bu amaçla, çalışmada Ocak 2011Aralık 2019 dönemine ait ay sonu hisse senedi endeksi fiyat verileri ile aynı döneme ait aylık perakende, inşaat ve hizmet sektörü güven endeksi verileri arasındaki sebep-sonuç ilişkisi araştırılmıştır. Sebep-sonuç ilişkisinin belirlenmesinde, Granger nedensellik testi kullanılmıştır. Çalışmada, hisse senedi endeksi olarak BiST 100 endeksi baz alınmıştır. İşlem hacmi ve piyasa bakımından en yüksek 100 hisseyi içermesi nedeniyle bu endeks seçilmiştir. Veriler, E-views 9 paket programı ile analiz edilmiştir. Analiz sonucunda BIST 100 endeksinden, perakende, inşaat ve hizmet sektörü güven endeksine doğru tek yönlü anlamlı ilişki olduğu görülmüştür.
\end{abstract}

Anahtar Kelimeler: BiST 100 Endeksi, Güven Endeksleri, Granger Nedensellik Testi

\section{A Study of relationship between share index and consumer confidence index, with Granger causality test}

\begin{abstract}
Confidence indices form a general opinion about the economy, as they examine the attitudes of households towards current and future behavior. These decisions are considered to be related to stock indices. For this purpose; In the study, the cause-effect relationship between the month-end stock index price data for the period January 2011 - December 2019 and the monthly retail, construction and service sector confidence index data for the same period was investigated. Granger causality test was used to determine the cause-effect relationship. In the study, BIST 100 index was taken as the stock index. This index was chosen because it contains the highest 100 shares in terms of trading volume and market. The data, were analyzed with E-views 9 package program. As a result of the analysis it was seen that there is a one-way significant relationship from the BIST 100 index to the retail, construction and service sector confidence index.
\end{abstract}

Key Words: BiST 100 Index, Confidence Indices, Granger Causality Test

$\quad$ ARTICLE INFO
Research Article
Received 5 December
2020
Received in revised form
14 March 2021
Received in revised form
15 March 2021
Accepted 19 March 2021

\section{Giriş}

Tüketici güven endeksi, ülke ekonomisinin gidişatı için bir yol haritası niteliğindedir. Çünkü bu endeks, hane halkının gelecekteki yatırım ve tasarruf kararlarına yön vermekte, beklentileri hakkında fikir vermektedir. Hane halkının piyasaya güven duyduğu bir ortamda, ekonomi olumlu anlamda etkilenecektir. Güvenin olmadığı bir ortamda, yatırımcı piyasadaki maddi beklentilerini azaltarak koşulların elverişli olduğu diğer piyasalara yönelecektir.

Anket sonuçları vasıtasıyla ölçülen ve birçok alt sektörden oluşan tüketici güven endeksi, 0-200 aralığında değer almaktadır. Eğer tüketici güven endeksi 100 'den büyük ise, tüketici güveni ve genel ekonomik durum hakkında iyimserliği, 100'den küçük olması halinde, tüketici güveni ve ekonomik seyirde kötümserliği ifade etmektedir. (www.tuik.com.tr, 2019). Çalışmada, tüketici güven endeksi verisi olarak inşaat,hizmet, perakende güven endeksi verileri seçilecektir. Sektörler arası güven endeksi verileri kullanılarak hisse senedi ile olan ilişkinin daha güçlü kurulması istenmiştir.

Hisse senedi fiyat endeksleri, hisse senetlerinin fiyat ve performansları hakkında bilgi veren endekslerdir. Bu endeksler yurt içi ve yurt dışı genel konjonktürden etkilenebilmektedir. Ülke ekonomisinin ve küresel pazarların seyri endekslerin hareketlerinde değişikliğe yol açmaktadır. Ekonominin iyiye gideceğine yönelik bir algı varsa, BiST 100 fiyat endeksinin artış göstermesi beklenilmektedir. BisT 100 fiyat endeksi, hisse senedi endeksleri içerisinde en yüksek hacimli 100 firmaya ait fiyat değişimlerine yer vermektedir. Hisse senedi endekslerinden BisT 100 fiyat endeksi seçilerek kapsamlı bir değerlendirme yapılması amaçlanmıştır. Çalışmada, BiST 100 fiyat endeksi ile inşaat, hizmet, perakende güven endeksi arasındaki sebep- sonuç ilişkisi, 2011 Ocak- 2019 Aralık dönemini kapsayarak incelenecektir.

\section{Literatür Taraması}

Tüketici güven endeksi ile pay senedi endeksi üzerine yapılan akademik çalışmalar incelendiğinde, çalışmalarda kullanılan yöntemin çoğunlukla Granger nedensellik testi olduğu görülmektedir. Granger nedensellik testinin yanı sıra, regresyon modelleri, Hatemi J asimetrik nedensellik testi, Toda-Yamamoto nedensellik testi, eş bütünleme testleri ve Diyagonal VECH modeli de kullanılmıştır. Ulaşılan sonuçlar genellikle hisse senedi endekslerinden, tüketici güven endekslerine doğru pozitif bir ilişki olduğu yönündedir. Elde edilen bazı sonuçlarda ise; tüketici güven endeksinden, hisse senedi endekslerine doğru ilişki olduğu görülürken, her iki endeks içerisinde herhangi bir ilişki durumunun mevcut olmadığı çalışmalar da bulunmaktadır.

Fisher ve Statman (2002), çalışmalarında S\&P 500 Endeksi ile tüketici güven endeksi arasındaki ilişkiyi, regresyon modeli ile incelemişlerdir. Analize, 19892002 yılları arasındaki veriler dahil edilmiştir. Tüketici güven endeksleri ile pay senedi endeksleri arasında, negatif yönlü bir ilişki olduğu sonucuna ulaşılmıştır. Tüketici güveni ve bireysel yatırımcıların duygularındaki değişimler arasında ise, olumlu ilişki olduğu görülmüştür. 
Jansen ve Nahius (2003), hisse senedi getirileri ile tüketici güven endeksi arasındaki ilişkiyi Granger nedensellik testi ile incelemişlerdir. Analiz kapsamına 1986-2001 yılları dahil edilmiş olup, çalışma 11 AB ülkesini içermektedir. 9 ülkeye ait veriler incelendiğinde, hisse senedi getirileri ile tüketici güven endeksi arasında pozitif korelasyon ilişkisi vardır.

Ferrera, Salaberb ve Zalewskac (2014), yapmış oldukları çalışma, 1990-2010 dönemine ait 12 AB ülkesini ve ABD'yi kapsamaktadır. Çalışmada, Granger nedensellik testi kullanılmıştır. Yatırımcı duyarlıı̆ı ile borsa hareketleri arasında pozitif ilişki olduğu tespit edilmiştir. Analize dahil edilen AB ülkelerinde yer alan borsaların, gelecekteki kişisel finansman algıları üzerinde etkisi olduğu sonucuna ulaşılmışır.

Salhin, Sherif ve Jones (2016), çalışmalarında, Ingiltere'de 1985-2014 yıllarını içeren hisse senedi endeks getirileri ile yatıımcı duyarlıı̆̆ı arasındaki ilişkiyi, Granger nedensellik testi ile incelemişlerdir.Yatırımcı duyarlıı̆ı̆ın, hisse senedi getirilerine önemli etkisi olduğu; özellikle inşaat ve imalat sektörüne ait duyarlılık verilerinden etkilendiği görülmüştür.

Usul, Küçüksille ve Karaoğlan (2017), çalışmalarında, BiST 100 endeksi ile tüketici güven endeksi ile reel kesim güven endeksi arasındaki ilişkiyi, KSS eş bütünleşme testi ile incelemişlerdir. Analize dahil edilen veriler, 2007 Ocak-2017 Ocak dönemini kapsamaktadır. Yapılan analiz sonucunda, güven endekslerinin, hisse senedi endeksini olumlu olarak etkilediği sonucuna ulaşıııışır.

Canöz (2018), BiST 100 endeks verileri ile tüketici güven endeksine ait verileri, 2004-2017 yılları arasında Toda-Yamamoto nedensellik testi ile analiz etmiştir. Uygulama sonucunda, hisse senedi endeksinden, tüketici güven endeksine yönelik bir nedensellik ilişkisi olduğu görülmüştür.

Tekin ve Cengiz (2018), çalışmalarında, Ocak 2004- Ağustos 2017 yıllarına ait tüketici güven endeksi ile hisse senedi endeksi arasındaki ilişkiyi, Granger nedensellik testi ile analiz etmişlerdir. BIST 100 endeksinin, tüketici güven endeksinin bir nedeni olduğu sonucuna ulaşılmıştır. Ayrıca yapılan eş bütünleme testine göre, veriler arasında uzun vadeli bir iliş̧i söz konusudur.

Eyüboğlu ve Eyüboğlu (2018) çalışmalarında, birçok sayıda hisse senedi endeksi ile tüketici güven endeksi arasındaki ilişkiyi ARDL modeli ile incelemişlerdir. Bu endeksler; BIST 100, BiST Gıda ve İçecek, BiST Ana Metal, BiST Tekstil vb. 18 endeksten oluşmaktadır. Analiz sonucunda, tüketici güven endeksinin neden, hisse senedi endekslerinin ise sonuç olduğu görülmektedir.

Münyas (2019), yapmış olduğu çalışmada, BIST 30, BIST 50 ve BIST 100 endeksine ait veriler ile reel kesim güven endeksi, tüketici güven endeksi, perakende ticaret sektörü güven endeksi, inşaat sektörü güven endeksi, ekonomik güven endeksi, hizmet sektörü güven endeksi verilerini kullanmıştır. Veriler 2011 Ocak2018 Eylül dönemini içermektedir. Analizde kantil regresyon modeli kullanılmıştır.Tüketici güven endeksi, ekonomik güven endeksi, reel kesim güven endeksi ile hisse senedi endeksi arasında ilişki olduğu sonucuna ulaşılmıştır.

Akkuş ve Zeren (2019), çalışmalarında Katılım- 30 hisse senedi endeks verileri ile tüketici güven endeksi verileri arasındaki ilişkiyi, Hatemi J asimetrik nedensellik testi kullanarak analiz etmişlerdir.Endeks veriler arasında bir ilişki olmadığı saptanmıştır. Sadece pozitif şokların yaşandığı dönemlerde, ilişkinin paralel olduğu sonucuna ulaşılımışır.

Gökalp (2019), yapmış olduğu çalışmada, 2002-2018 yıllarına ait tüketici güven endeksi verileri ile BíST 100 endeksine ait veriler arasındaki ilişkiyi Diyagonal VECH modeli ile incelemiştir.Tüketici güven endeksinden, hisse senedeki endeksine doğru bir yayılma olduğu sonucuna ulaşılmış olup, veriler arasında bir volatilite ilişkisi olduğu görülmüştür.

Baştürk (2020), çalışmasında, 2004 Ocak- 2019 Mart dönemine ait tüketici güven endeksi ile BiST 100 endeksi arasındaki ilişkiyi Granger nedensellik testi ile incelemiştir.Hisse senedi endeksinden, tüketici güven endeksine tek yönlü nedensellik olduğu, yapılan diğer akademik çalışmalar ile benzer sonuç elde edildiği tespit edilmiştir.

\section{Yöntem}

Granger nedensellik testinin, özellikle son yıllarda finans alanında yapılan çalışmalarda kullanıldığı görülmektedir. Granger nedensellik testi, karşılaştırmak istenilen seriler arasında herhangi bir ilişkinin olup olmadığını göstermek amacı ile kullanılan bir yöntemdir. Bu testin sonucunda, seriler arasında tek yönlü veya çift yönlü nedensellik ilişkisi olabilmektedir. Böylelikle istenen veriler arasında sebep-sonuç ilgisi kurulabilmektedir. Granger nedensellik testinin yapılabilmesi için; serilerin durağanlığı sağlanacak ve VAR modeli oluşturulacaktır.

\subsection{Birim Kök Testi ve VAR Modeli}

Üzerinde analiz yapılacak olan seriler eğer durağan değilse, istatistiki açıdan ulaşılan sonuçlar anlamlı olmamaktadır. Bu sebeple tahmin yapabilmek ve birtakım istatistiki sonuçları sağlayabilmek için, serilerin durağanlaştırılması gerekmektedir. Ayrıca birim kök testleri, serilerde farkın kaçıncı dereceden durağan olduğunun tespit edilmesinde de kullanılmaktadır. Analize dahil edilen serilere ait veriler, durağanlaştırılıncaya kadar fark alınma işlemi devam etmektedir. Serinin karakteristik denklemin köklerinin 1'den küçük olması durumunda, seri için durağandır yorumu yapılabilmektedir.(Göktaş, Pekmezci ve Bozkurt, 2019:78). Birim kök testine ilişkin hipotezler şu şekildedir: HO: Seri durağanlık şartını sağlamamaktadır. (birim kök içermektedir) H1: Seri durağanlık şartını sağlamaktadır. (birim kök içermemektedir)

Bu çalışmada birim kök testi olarak, Augmented Dickey-Fuller kullanılacaktır. Testin en yalın hali, Formül 1 yardımı ile gösterilmiştir. $\Delta \mathrm{Y}_{\mathrm{t}}=(\rho-1) \mathrm{Y}_{(\mathrm{t}-1)}+\mathrm{u}_{\mathrm{t}}$

VAR modelinin yapılabilmesi için, ayrı ayrı serilerin durağanlığı test edildikten sonra, aşağıdaki adımlar izlenecektir:(Bose, Hravnak ve Sereika, 2017:15). 1.

2. Gecikme uzunluğu seçim kriterleri kullanılarak belirlenecek ve böylelikle uygun gecikmelere sahip bir VAR modeli oluşturulacaktır.

Oluşturulan bu set, otokorelasyon (Lagrange Çarpanı (LM)) testine tabi tutulacaktır.

VAR modelinin kararlıı̆̆ı, otoregresif kökler tablosu ile belirlenecektir.

Tüm bu şartlar sağlandıktan sonra, veri seti Granger nedensellik testi yapmaya uygun hale gelecektir.

VAR modelinin kurulabilmesi için, uygun gecikme uzunluğu bulunurken, Akaike bilgi kriterine göre karar verilecektir.Gecikme uzunluğu belirlendikten sonra yapılacak olan otokorelasyon testinde, otokorelasyon istenmeyen bir durumken, serinin kararlılığı istenilen bir durumdur.

Otokorelasyon, hata terimleri arasında ilişki olduğuna işaret etmektedir. Otokorelasyonun olması durumunda parametrelerin en küçük kareler tahmincileri sapmasız ve tutarlı olup, etkin olmadığı sonucuna ulaşılmaktadır. Anlamsız bir katsayının anlamlı olma ihtimali artmaktadır. Sonuç olarak $\mathrm{t}$ ve $\mathrm{F}$ testleri güvenilirliğini yitirmekte, istatistiki açıdan yanlış sonuçlar verilmesine sebep olmaktadır.(Yavuz, 2009:126). Yapılan akademik çalışmalarda otokorelasyon sorununun tespiti için, genellikle son yıllarda Breusch-Godfrey testinin kullanıldığı görülmektedir. Bu test sonucunda ilgili değerin 0,05'ten yüksek olması istenilen durumdur.

Kararlılık, modelin zaman serisinin, örnekleme üzerinde nasıl geliştiğinin iyi bir temsili olup olmadığını kontrol etmektedir. Katsayı matrisinin karakteristik polinomunun kökleri kullanılarak değerlendirilmektedir. Bir VAR modelindeki kararlılık, tümü 0'dan küçük olan ve grafikte yer alan köklerle gösterilmektedir. (Bose, Hravnak ve Sereika, 2017:16). Kararlılığa yönelik sonuçlar, grafik yardımı ile elde edildiğinde, kökler eğer çemberin içinde yer almış ise; kullanılan modelin kararlı olduğu sonucuna ulaşılmaktadır. Kararlılık bilgisine, grafiğin yanı sıra, analiz sonucunda elde edilen tablo ile de ulaşılabilmektedir. illgili tablo sonunda, kararlılık koşulu sağlanmıştır bilgisi yer aldığında, serinin kararlılık şartını sağlamış olduğu kabul edilmektedir.

\subsection{Granger Nedensellik Testi}

Granger nedensellik testine ait model, formül 2 yardımıyla gösterilmektedir. Bu test, formül 2 ve formül 3'de bulunan , bağımsız değişkenlerin gecikmeli değerlerine ait olan katsayıların, belirli bir anlamlılık düzeyinde grup olarak sıfıra eşit olup olmadığını analiz etmektedir. Formül 2'deki katsayılar belirli bir anlamlılık düzeyinde sıfırdan farklı bulunursa, X'in Y'nin Granger nedeni olduğu sonucuna ulaşılmaktadır. Formül 3'e ait kat sayılar da belirli bir anlamlılık düzeyinde sıfırdan farklı bulunduğunda, Y'nin X'in Granger nedeni olduğu sonucu elde edilmektedir.(Öner, 2018:322).

$y_{1 t}=\alpha_{10}+\beta_{11} y_{1 t-1}+\beta_{12} y_{2 t-1}+\gamma_{11} y_{1 t-2}+\gamma_{12} y_{2 t-2}+\delta_{11} y_{1 t-3}+\delta_{12} y_{2 t-3}+u_{1 t}$ (2)

$y_{2 t}=\alpha_{20}+\beta_{21} y_{1 t-1}+\beta_{22} y_{2 t-1}+\gamma_{21} y_{1 t-2}+\gamma_{22} y_{2 t-2}+\delta_{21} y_{1 t-3}+\delta_{22} y_{2 t-3}+u_{2 t}$ (3) 


\section{Analiz ve Bulgular}

\subsection{Veri Seti}

Bu çalışmada 2011 Ocak- 2019 Aralık yıllarına ait aylık inşaat, hizmet, perakende ticaret güven endeksi verileri ile ay sonu BiST 100 endeksine ait fiyat verileri kullanılarak nedensellik analizi test edilmektedir. Güven endekslerine ait veriler www.tüik.com adresinden, ay sonu BiST 100 fiyat endeksine ait veriler www.investing.com.tr 'den elde edilmiştir. Verilere yönelik uygulanan Granger nedensellik testinde kullanılacak olan program, E-views 9 paket programıdır.

\subsection{Birim Kök Testi}

Çalışmada kullanılan birim kök testi Genişletilmiş Dickey-Fuller birim kök testidir. Birim kök testi yapılmasındaki amaç, serilere ait verilerin durağanlığını tespit etmektir. Serinin birim kök içermemesi, durağanlık şartını sağladığını göstermektedir.

Tablo 1. Inşaat güven endeksinin birim kök testi sonuçları

\begin{tabular}{|c|c|c|}
\hline Sabitsiz & t- Statistic & Prob.* \\
\hline & -1.13 & 0.24 \\
\hline \%1 level & -2.59 & \\
\hline$\% 5$ level & -1.94 & \\
\hline \%10 level & -1.61 & \\
\hline \multirow[t]{2}{*}{ Sabitli } & t- Statistic & Prob.* \\
\hline & -2.41 & 0.15 \\
\hline \%1 level & -3.49 & \\
\hline$\% 5$ level & -2.89 & \\
\hline \%10 level & -2.58 & \\
\hline \multirow[t]{2}{*}{ Sabitli Trendli } & t- Statistic & Prob.* \\
\hline & -4.41 & 0.00 \\
\hline \%1 level & -4.05 & \\
\hline \%5 level & -3.45 & \\
\hline \%10 level & -3.15 & \\
\hline
\end{tabular}

Tablo 1'de, inşaat güven endeksine ait serilerin sabitsiz, sabitli ve sabitli trendli birim kök olasılık değerleri sırası ile \%24, \%15 ve \%0 'dır. Sabitli trendli birim kök testi sonucu 0,05 'ten küçük olduğundan, HO hipotezi reddedilmiştir. Sabitsiz, sabitli ve sabitli trendli birim kök testi sonuçlarından herhangi birinin 0,05'ten küçük olması, serinin durağan olması için yeterlidir. Bu sebeple veriler durağandır, birim kök içermemektedir.

Tablo 2. Perakende güven endeksinin birim kök testi sonuçları

\begin{tabular}{|c|c|c|}
\hline Sabitsiz & t- Statistic & Prob.* \\
\hline & -0.94 & 0.31 \\
\hline \%1 level & -2.59 & \\
\hline \%5 level & -1.94 & \\
\hline \%10 level & -1.61 & \\
\hline \multirow[t]{2}{*}{ Sabitli } & t- Statistic & Prob.* \\
\hline & -5.18 & 0.00 \\
\hline \%1 level & -3.49 & \\
\hline$\% 5$ level & -2.89 & \\
\hline$\% 10$ level & -2.58 & \\
\hline \multirow[t]{2}{*}{ Trendli } & t- Statistic & Prob.* \\
\hline & -7.23 & 0.00 \\
\hline \%1 level & -4.05 & \\
\hline \%5 level & -3.45 & \\
\hline \%10 level & -3.15 & \\
\hline
\end{tabular}

Tablo 2'de, perakende güven endeksine ait serilerin sabitsiz, sabitli ve sabitli trendli birim kök olasılık değerleri sırası ile \%31, \%0 ve \%0 çıkmıştır. Sabitli ve trendli birim kök olasılık değeri 0,05'ten küçük olduğundan, H1 hipotezi kabul edilmiştir. Seriye ait veriler durağandır ve birim kök içermemektedir yorumu yapılabilmektedir.

Tablo 3. Hizmet güven endeksinin birim kök testi sonuçları

\begin{tabular}{|c|c|c|}
\hline Sabitsiz & t- Statistic & Prob.* \\
\hline & -1.37 & 0.16 \\
\hline \%1 level & -2.59 & \\
\hline \%5 level & -1.94 & \\
\hline \%10 level & -1.61 & \\
\hline
\end{tabular}




\begin{tabular}{|c|c|c|}
\hline Sabitli & t- Statistic & Prob.* \\
\hline & -3.41 & 0.01 \\
\hline \%1 level & -3.49 & \\
\hline \%5 level & -2.89 & \\
\hline \%10 level & -2.58 & Prob.* \\
\hline Trendli & t- Statistic & 0.00 \\
\hline & -5.82 & \\
\hline \%1 level & -4.05 & \\
\hline \%5 level & -3.45 & \\
\hline \%10 level & -3.15 & \\
\hline
\end{tabular}

Tablo 3'te de, inşaat ve perakende güven endekslerine benzer sonuçlar görülmüştür. Sabitsiz, sabitli ve sabitli trendli birim kök olasılık değerleri sırası ile $\% 16, \% 1$ ve $\% 0$ 'dır. Hizmet güven endeksine ait serilerin sabitli ve trendli birim kök olasılık değeri 0,05'ten küçüktür. H1 hipotezi kabul edilerek, serilerin durağan ve birim kök içermediği bilgisine ulaşıımıştır.

\begin{tabular}{|c|c|c|}
\hline \multicolumn{2}{|c|}{ Tablo 4. Bist 100 fiyat endeksinin birim kök testi sonuçları } \\
\hline Sabitsiz & t- Statistic & Prob.* \\
\hline \%1 level & 0,72 & 0,87 \\
\hline \%5 level & $-2,59$ & \\
\hline \%10 level & $-1,94$ & \\
\hline Sabitli & $-1,61$ & Prob. $^{*}$ \\
\hline & t- Statistic & 0,66 \\
\hline \%1 level & $-1,23$ & \\
\hline \%5 level & $-3,50$ & \\
\hline \%10 level & $-2,89$ & Prob.* \\
\hline Sabitli Trendli & $-2,58$ & 0,12 \\
\hline & t- Statistic & \\
\hline \%1 level & $-3,08$ & \\
\hline \%1 level & $-4,05$ & \\
\hline
\end{tabular}

Tablo 4'de, birim kök testinin de benzer bir sonuç verdiği görülmektedir. BiST 100'e ait sabitsiz, sabitli ve sabitli trendli birim kök olasılık değerleri sırası ile \%87, \%66 ve \%12 olarak elde edilmiştir. BiST 100 endeksi fiyat verilerine ait serinin olasılık değeri 0,05'ten küçük olmadığından, H0 hipotezi kabul edilememiştir. Bu sebeple, veriler durağan değildir ve birim kök içermektedir yorumu yapılabilmektedir. Verilerin durağanlaştırılması için, seriye fark alınma işlemi uygulanacaktır. Fark alındıktan sonra, verilerin durağanlaştığı sonucuna ulaşılmıştır. Serinin fark alınmasına ilişkin tablo, ek 1'de verilmiştir.

\subsection{Gecikme Uzunluğunun Belirlenmesi}

Serilerin gecikme uzunluğu VAR analizi ile tahmin edilecektir. Çalışmada, Akaike bilgi kriterine göre gecikme uzunluğu 8 olarak belirlenmiştir. Akaike bilgi kriterine göre en düşük AIC değeri, en iyi değer olarak kabul edilmektedir. Bu nedenle analizde gecikme kat sayısı 8 olarak kullanılacaktır. Gecikme uzunluğunun belirlenmesine ilişkin tablo, Tablo 5'de gösterilmiştir.

Tablo 5. Gecikme uzunluğunun belirlenmesi
\begin{tabular}{|c|c|c|c|c|c|c|}
\hline Lag & LogL & LR & FPE & AIC & SC & HQ \\
\hline 0 & -1957.13 & NA & $1.89 \mathrm{e}+12$ & 39.62 & 39.72 & 39.66 \\
\hline 1 & -1744.55 & 403.69 & $3.56 \mathrm{e}+10$ & 35.65 & $36.17^{*}$ & 35.86 \\
\hline 2 & -1715.53 & 52.76 & $2.74 \mathrm{e}+10$ & 35.38 & 36.33 & $35.77^{*}$ \\
\hline 3 & -1699.03 & 28.65 & $2.73 \mathrm{e}+10$ & 35.37 & 36.74 & 35.93 \\
\hline 4 & -1687.00 & 19.93 & $2.98 \mathrm{e}+10$ & 35.45 & 37.24 & 36.18 \\
\hline 5 & -1675.73 & 17.76 & $3.32 \mathrm{e}+10$ & 35.56 & 37.75 & 36.44 \\
\hline 6 & -1659.44 & 24.36 & $3.36 \mathrm{e}+10$ & 35.54 & 38.17 & 36.60 \\
\hline 7 & -1641.30 & 25.65 & $3.30 \mathrm{e}+10$ & 35.50 & 38.54 & 36.73 \\
\hline 8 & -1613.53 & $37.03^{*}$ & $2.70 \mathrm{e}+10^{*}$ & $35.26^{*}$ & 38.72 & 36.66 \\
\hline
\end{tabular}

Oluşturulan VAR modelinde otokorelasyon ve kararlıık şartı da sağlanmıştır. Otokorelasyon hata terimleri arasında ilişki olması durumudur. Otokorelasyon olması durumunda, serilerin anlamlı olup olmadığı hakkında yorum yapılamamaktadır. Bunun için serinin olasılık değerinin 0,05 'ten büyük olması istenilmektedir. Yapılan kararlılık testi sonucunda da (tablo biçiminde gösterim tercih edilmiştir) bütün köklerin tablonun içerisinde yer aldığı bilgisine ulaşılmıştır. Böylelikle VAR modeli, kararlılık koşulunu da karşılamıştır. Ayrıca oluşturulan modele ek olarak, değişen varyans ve normallik koşulları da sağlanmıştır. Bunlara ilişkin test sonuçları, ek 2,3,4 ve 5'te verilmiştir.

\subsection{Granger Nedensellik Testi}

Tablo 6. Granger nedensellik testi sonuçları

\begin{tabular}{|c|c|c|c|}
\hline \multicolumn{4}{|c|}{ Dependent variable: BIST_BIRINCI_FARK } \\
\hline Excluded & Chi-sq & df & Prob. \\
\hline HIZMET & 9.14 & 8 & 0.33 \\
\hline
\end{tabular}




\begin{tabular}{|c|c|c|c|}
\hline PERAKENDE & 4.89 & 8 & 0.77 \\
\hline TRENDARINDIRILMIS_INSAAT & 2.33 & 8 & 0.97 \\
\hline All & 20.38 & 24 & 0.68 \\
\hline Excluded & Chi-sq & df & Prob. \\
\hline BIST_BIRINCI_FARK & 25.85 & 8 & 0.01 \\
\hline PERAKENDE & 8.02 & 8 & 0.43 \\
\hline TRENDARINDIRILMIS_INSAAT & 43.77 & 8 & 0.00 \\
\hline All & 85.94 & 24 & 0.00 \\
\hline \multicolumn{4}{|c|}{ Dependent variable: PERAKENDE } \\
\hline Excluded & Chi-sq & df & Prob. \\
\hline BIST_BIRINCI_FARK & 17.76 & 8 & 0.02 \\
\hline HIZMET & 15.82 & 8 & 0.05 \\
\hline TRENDARINDIRILMIS_INSAAT & 33.99 & 24 & 0.00 \\
\hline All & 74.75 & df & 0.00 \\
\hline \multicolumn{4}{|c|}{ Dependent variable: TRENDARINDIRILMIS_INSAAT } \\
\hline BIST_BIRINCI_FARK & Chi-sq & 8 & 0.03 \\
\hline HIZMET & 23.26 & 8 & 0.11 \\
\hline PERAKENDE & 12.93 & 8 & 0.00 \\
\hline All & 25.26 & 24 & 0.00 \\
\hline
\end{tabular}

E- views 9 paket programından elde edilen Granger nedensellik testi sonucuna göre, BiST 100 ve hizmet, perakende, inşaat güven endeksi verileri arasında nedensellik ilişkisinin kurulabilmesi için, endekslere ait olasılık değerlerinin 0,05'ten küçük olması istenilmektedir. Tablo 6'da sırası ile BiST 100, hizmet, perakende ve inşaat verilerinin bağımlı değişken olduğu görülmektedir. BiST 100'ün bağımlı değişken olduğu olasılık değerlerine bakıldığında, değerlerin 0,05'ten büyük olduğu görülmektedir. Buna göre, hizmet, perakende ve inşaat güven endekslerinin, BiST 100 üzerinde herhangi bir etkisi yoktur, aralarında Granger nedensellik ilişkisi bulunmamaktadır. Hizmet, perakende ve inşaat güven endekslerinin bağımlı değişken olduğu olasılık değerlerine bakııdığında ise, değerlerin $0,05^{\prime}$ ten küçük olduğu görülmektedir. Olasılık değerleri sırası ile $\% 0 \% 2$ ve $\% 3$ olarak gerçekleşmiştir. Bu sonuç, BiST 100'ün, hizmet, perakende ve inşaat güven endeksleri üzerinde etkisi olduğunu göstermektedir. Yapılan analize göre, veriler arasında Granger nedensellik ilişkisi bulunmaktadır. İlişki, BiST 100 endeksinden, güven endekslerine doğru tek yönlü olarak gerçekleşmiştir. Diğer bir deyişle, BisT 100 endeksinin, güven endeksleri üzerinde anlamlı etkisi vardır. BIST 100 endeksi, hizmet,perakende ve inşaat güven endekslerinin Granger nedenidir. Hizmet, perakende ve inşaat güven endeksi ise sonucudur.

\section{Tartışma ve Sonuç}

Davranışsal finansın son yıllarda ivme kazanmasıyla, tüketici davranışları ile ekonomik hareketlerin birbirinden etkilendiği görülmektedir. Yatırımcılar, karar alırken enflasyon, faiz gibi makro ekonomik göstergelerin yanında, tüketicilerin harcama ve tasarruflarını etkileyen güven endekslerini de dikkate almaktadır. Yatırımcılar çoğunlukla rasyonel değil, irrasyonel davranma eğilimindedirler. Dolayısı ile yatırımcıların davranışları değişiklik gösterebilmekte, bu değişiklikler borsa hareketlerine yansıyabilmektedir. Bu doğrultuda çalışmada, çeşitli sektörlere ait güven endeksi verileri ile BisT 100 endeksi fiyat verileri arasındaki ilişkinin incelenmesi amaçlanmıştır.

Çalışmada, aylık ölçülen perakende, hizmet, inşaat güven endeksi verileri ile ay sonu BísT 100 endeksine ait fiyat verileri, 2011 Ocak-2019 Aralık dönemini kapsayacak şekilde incelenmiştir. Analizde E-views 9 paket programı kullanılarak, veriler Granger nedensellik testi ile analiz edilmiştir. Uygulama neticesinde, BiST 100 endeksinden, hizmet, perakende ve inşaat güven endekslerine doğru tek yönlü ilişki olduğu sonucuna ulaşılmıştır. Diğer bir deyişle; BisT 100 endeksinin, güven endeksine ait veriler üzerinde anlamlı bir etkisi vardır. BisT 100’ de yaşanan artışlar, güven endekslerini olumlu yönde etkileyecektir. Elde edilen sonucun, yapılan ilgili çalışmalar ile benzerlik gösterdiği görülmektedir. Bazı çalışmalarda güven endekslerinin, hisse senedi endekslerini etkilediği görülürken, bazılarında ise endeksler arasında herhangi bir ilişkiye rastlanmamıştır.

Sonuçtan hareketle, pay senedi endeksindeki iyileşmelerin, tüketicide güven etkisi yarattığı söylenebilmektedir. Bu güvenin, ekonomik gidişat üzerinde olumlu etkisi olacağı düşünülmektedir. Pay senedi piyasalarındaki fiyat hareketlerinde, güven endekslerinin dikkate alınması gereken göstergelerden biri olduğu görülmektedir. Elde edilen sonucun, yatırımcılara kısa veya uzun vadeli yatırım kararlarında yardımcı olması beklenilmektedir.

\section{Kaynakça}

Akkuş, H. T. Zeren, F. (2019). Tüketici güven endeksi ve katılım-30 islami hisse senedi endeksi arasındaki saklı ilişkinin araştırılması: türkiye örneği, Üçüncü Sektör Sosyal Ekonomi Dergisi, 54(1), 53-70.

Baştürk M. F. (2020). Tüketici güven endeksi ile hisse senedi piyasası arasındaki ilişki: türkiye örneği. Maliye Dergisi, 177, $145-159$.

Bose, E., Hravnak, M., \& Sereika, S. M. (2017). Vector autoregressive models and Granger causality in time series analysis in nursing research. Nursing Research, 66(1), 12-19.

Canöz, í. (2018). Borsa istanbul 100 endeksi ile tüketici güven endeksleri arasındaki nedensellik ilişkisi: türkiye örneği. Fiscaoeconomia, 2(1), 136-153.

Eyüboğlu, S., Eyüboğlu, K. (2018). Tüketici güven endeksi ile borsa istanbul sektör endeksleri arasındaki ilişkinin araştırılması. Dokuz Eylül Üniversitesi Iktisadi ve Idari Bilimler Fakültesi Dergisi, 33(1), 235-259.

Ferrer, E., Salaber, J., Zalewska, A. (2014). Consumer confidence indices and stock markets' meltdowns. The European Journal Of Finance, 22(3), 195-220.

Fisher, K. L., Statman, M. (2003). Consumer confidence and stock returns. The Journal of Portfolio Management, 30(1), $115-127$.

Gökalp, B. (2019). Hisse senedi getirileri ile tüketici güven endeksi arasındaki ilişki: diyagonal vech modeli üzerinden bir değerlendirme. Ekonomi Politika ve Finans Araştırmaları Dergisi , 4(1), 139-150.

INVESTING BIST 100 Endeksi (2020). Erişim Adresi: http://tr.investing.com/indices/ise-100 (Erişim Tarihi: 18.06.2020).

Jansen, W.J., Nahuis, N.J. (2003). The stock market and consumer confidence: european evidence, Economics Letters, 79(1), 89-98.

Münyas, T. (2019). Borsa istanbul endeksleri ile güven endeksleri arasındaki ilişkinin araştırılması üzerine bir inceleme. Tesam Akademi Dergisi, Türkiye Ekonomisi Özel Sayısı, 299-320.

Öner, H. (2018). Tüketici ve üretici fiyat endeksleri arasındaki ilişkinin Granger nedensellik testi yoluyla incelenmesi. Finans Ekonomi ve Sosyal Araştırmalar Dergisi , 3(1) , 318-327.

Salhin, A., Sherif, M., Jones, E. (2016). Managerial sentiment, consumer confidence and sector returns. International Review Of Financial Analysis, 47, 24-38.

Tekin, B., Cengiz, S. (2018). Pay senedi piyasası ile tüketici güven endeksi arasındaki nedensellik ve eşbütünleşme ilişkileri: borsa istanbul'da bir uygulama. Journal of Social And Humanities Sciences Research, 5(29), 3837-3847.

TÜiK Haber Bülteni (2020). Erişim Adresi: http://www.tuik.gov.tr/PreHaberBultenleri.do?id=27865\&utm_source (Erişim Tarihi:16.6.2020).

Usul H., Küçüksille H., Karaoğlan, S. (2017). Güven endekslerindeki değişimlerin hisse senedi piyasalarına etkileri: borsa istanbul örneği. Süleyman Demirel Üniversitesi Iktisadi ve Idari Bilimler Fakültesi Dergisi, 22(3), 685-695. 
Yavuz, S . (2010). Hataları ardışık bağımlı (otokorelasyonlu) olan regresyon modellerinin tahmin edilmesi . Atatürk Üniversitesi Iktisadi Ve Idari Bilimler Dergisi , 23(3) , 123-140. 
Ek 1. BIST100'ün 1.dereceden farkının alınması

\begin{tabular}{|c|c|c|}
\hline Sabitsiz & t- Statistic & Prob. $^{*}$ \\
\hline & -11.06 & 0.00 \\
\hline \%1 level & -2.59 & \\
\hline \%5 level & -1.94 & \\
\hline \%10 level & -1.61 & Prob. $^{*}$ \\
\hline Sabitli & t- Statistic & 0.00 \\
\hline & -11.12 & \\
\hline \%1 level & -3.49 & Prob. \\
\hline \%5 level & -2.89 & 0.00 \\
\hline \%10 level & -2.59 & \\
\hline Trendli & t- Statistic & \\
\hline \%5 level & -11.09 & \\
\hline \%10 level & -4.04 & \\
\hline
\end{tabular}

Ek 2. Otokorelasyon test sonuçları

\begin{tabular}{|c|c|c|c|c|c|c|}
\hline Lag & LRE* stat & df & Prob. & Rao F-stat & df & Prob. \\
\hline 1 & 11.57 & 16 & 0.78 & 0.72 & $(16,18)$ & 0.77 \\
\hline 2 & 33.20 & 32 & 0.41 & 1.04 & $(32,20)$ & 0.41 \\
\hline 3 & 56.87 & 48 & 0.18 & 1.21 & $(48,20)$ & 0.18 \\
\hline 4 & 75.00 & 64 & 0.16 & 1.20 & $(64,19)$ & 0.18 \\
\hline 5 & 83.12 & 80 & 0.38 & 1.04 & $(80,18)$ & 0.41 \\
\hline 6 & 96.80 & 96 & 0.46 & 0.99 & $(96,16)$ & 0.51 \\
\hline 7 & 120.32 & 112 & 0.28 & 1.06 & $(112,15)$ & 0.35 \\
\hline 8 & 136.56 & 128 & 0.29 & 1.04 & $(128,13)$ & 0.41 \\
\hline
\end{tabular}

Ek 3. Kararlıık testi sonuçları

\begin{tabular}{|c|c|}
\hline Root & Modulus \\
\hline $0.850434+0.497650 \mathrm{i}$ & 0.99 \\
\hline $0.850434-0.497650 i$ & 0.99 \\
\hline $0.948277-0.159478 i$ & 0.99 \\
\hline $0.948277+0.159478 i$ & 0.99 \\
\hline 0.945341 & 0.94 \\
\hline$-0.424104-0.825019 i$ & 0.92 \\
\hline$-0.424104+0.825019 i$ & 0.93 \\
\hline $0.439710+0.815500 \mathrm{i}$ & 0.93 \\
\hline $0.439710-0.815500 \mathrm{i}$ & 0.93 \\
\hline$-0.810242+0.375831 i$ & 0.89 \\
\hline$-0.810242-0.375831 \mathrm{i}$ & 0.89 \\
\hline $0.460291-0.738960 \mathrm{i}$ & 0.87 \\
\hline $0.460291+0.738960 \mathrm{i}$ & 0.87 \\
\hline$-0.857930+0.085567 i$ & 0.86 \\
\hline$-0.857930-0.085567 i$ & 0.86 \\
\hline$-0.719206+0.454787 i$ & 0.85 \\
\hline$-0.719206-0.454787 i$ & 0.85 \\
\hline $0.327551-0.776951 \mathrm{i}$ & 0.84 \\
\hline $0.327551+0.776951 i$ & 0.84 \\
\hline$-0.037824-0.819338 \mathrm{i}$ & 0.82 \\
\hline$-0.037824+0.819338 i$ & 0.82 \\
\hline $0.632137+0.521005 i$ & 0.82 \\
\hline $0.632137-0.521005 i$ & 0.82 \\
\hline$-0.512730-0.620208 \mathrm{i}$ & 0.80 \\
\hline$-0.512730+0.620208 i$ & 0.80 \\
\hline 0.804630 & 0.80 \\
\hline$-0.302536-0.718328 i$ & 0.78 \\
\hline$-0.302536+0.718328 i$ & 0.78 \\
\hline $0.565114+0.288804 i$ & 0.63 \\
\hline $0.565114-0.288804 \mathrm{i}$ & 0.63 \\
\hline$-0.374539-0.240261 i$ & 0.44 \\
\hline$-0.374539+0.240261 i$ & 0.44 \\
\hline \multicolumn{2}{|c|}{$\begin{array}{l}\text { No root lies outside the unit circle. } \\
\text { VAR satisfies the stability condition. }\end{array}$} \\
\hline
\end{tabular}


Ek 4. Değişen varyans testi (var residual heteroskedasticity tests)

\begin{tabular}{|c|c|c|}
\hline \multicolumn{3}{|c|}{ Joint test: } \\
\hline Chi-sq & $\mathrm{df}$ & Prob. \\
\hline 616.44 & 640 & 0.74 \\
\hline
\end{tabular}

\begin{tabular}{|c|c|c|c|c|c|}
\hline \multicolumn{7}{|c|}{ Individual components: } \\
\hline Dependent & R-squared & $\mathrm{F}(64,34)$ & Prob. & Chi-sq(64) & Prob. \\
\hline res1*res1 & 0.70 & 1.27 & 0.22 & 69.83 & 0.29 \\
\hline res2*res2 & 0.65 & 1.00 & 0.51 & 64.72 & 0.45 \\
\hline res3*res3 & 0.67 & 1.08 & 0.41 & 66.46 & 0.39 \\
\hline res4*res4 & 0.53 & 0.60 & 0.96 & 52.49 & 0.85 \\
\hline res2*res1 & 0.57 & 0.69 & 0.90 & 56.03 & 0.75 \\
\hline res3*res1 & 0.57 & 0.70 & 0.89 & 56.44 & 0.74 \\
\hline res3*res2 & 0.66 & 1.02 & 0.49 & 65.05 & 0.44 \\
\hline res4*res1 & 0.66 & 1.03 & 0.48 & 65.25 & 0.43 \\
\hline res4*res2 & 0.63 & 0.92 & 0.62 & 62.83 & 0.52 \\
\hline res4*res3 & 0.66 & 1.009 & 0.50 & 64.85 & 0.45 \\
\hline
\end{tabular}

Ek 5. Normallik testi

\begin{tabular}{|c|c|c|c|c|}
\hline Component & Skewness & Chi-sq & df & Prob.* \\
\hline 1 & 0.12 & 0.225951 & 1 & 0.63 \\
\hline 2 & -0.06 & 0.066006 & 1 & 0.80 \\
\hline 3 & 0.049 & 0.038966 & 1 & 0.84 \\
\hline 4 & 0.04 & 0.022913 & 1 & 0.88 \\
\hline Joint & & 0.353837 & 4 & 0.99 \\
\hline Component & Kurtosis & Chi-sq & df & Prob. \\
\hline 1 & 2.67 & 0.475803 & 1 & 0.49 \\
\hline 2 & 2.56 & 0.804086 & 1 & 0.37 \\
\hline 3 & 2.87 & 0.070162 & 1 & 0.79 \\
\hline 4 & 3.03 & 0.003446 & 1 & 0.95 \\
\hline Joint & & 1.353498 & 4 & 0.85 \\
\hline Component & Jarque-Bera & df & Prob. & \\
\hline 1 & 0.70 & 2 & 0.70 & \\
\hline 2 & 0.88 & 2 & 0.65 & \\
\hline 3 & 0.11 & 2 & 0.95 & \\
\hline 4 & 0.03 & 2 & 0.99 & \\
\hline Joint & 1.71 & 8 & 0.99 & \\
\hline
\end{tabular}

